\title{
Sodium status of soil, forages, and small ruminants of Punjab, Pakistan
}

\author{
Samra Siddique ${ }^{1}$, Kafeel Ahmad ${ }^{1}$, Zafar Iqbal Khan ${ }^{1 *}$, Kinza Wajid ${ }^{1}$, \\ Humayun Bashir ${ }^{1}$, Mudasra Munir ${ }^{1}$, Muhammad Nadeem ${ }^{2}$, Ijaz Rasool \\ Noorka $^{3}$, Ifra Saleem Malik ${ }^{1}$, Asma Ashfaq ${ }^{1}$, Ilker Ugulu ${ }^{4}$, Mubeen \\ Akhtar $^{1}$, Pervaiz Akhtar ${ }^{1}$, Naunain Mehmood ${ }^{5}$, Hira Muqadas ${ }^{6}$ and \\ Mahpara Shehzadi ${ }^{7}$ \\ 1. Department of Botany, University of Sargodha-Pakistan \\ 2. Institute of Food Science and Nutrition, University of Sargodha-Pakistan \\ 3. Department of Plant Breeding and Genetics, University College of Agriculture, University of Sargodha-Pakistan \\ 4. Faculty of Education, Usak University, Usak-Turkey \\ 5. Department of Zoology, University of Sargodha-Pakistan \\ 6. Department of Zoology, Women University Multan-Pakistan \\ 7. Department of Agriculture, Ghazi University, Dera Ghazi Khan-Pakistan \\ *Corresponding author's email: zafar.khan@uos.edu.pk \\ Citation \\ Samra Siddique, Kafeel Ahmad, Zafar Iqbal Khan, Kinza Wajid, Humayun Bashir, Mudasra Munir, Muhammad \\ Nadeem, Ijaz Rasool Noorka, Ifra Saleem Malik, Asma Ashfaq, Ilker Ugulu, Mubeen Akhtar, Pervaiz Akhtar, \\ Naunain Mehmood, Hira Muqadas and Mahpara Shehzadi. Sodium status of soil, forages, and small ruminants of \\ Punjab, Pakistan. Pure and Applied Biology. Vol. 8, Issue 3, pp1950-1961. \\ http://dx.doi.org/10.19045/bspab.2019.80139
}

Received: 15/05/2019

Revised: 10/07/2019

Accepted: 16/07/2019

Online First: 23/07/2019

\section{Abstract}

The present investigation was aimed to search out the sodium level in soil, forages and blood samples of the small ruminants (goat and sheep) of three districts of Punjab, Pakistan. Most forage and soil samples were found deficient in sodium contents. The lower level of $\mathrm{Na}$ was found in soil as well as in forages of three districts (Sargodha, Mianwali, Bhakkar). Most of the forage samples are so deficient in Na contents that they fall much below the critical levels known to be adequate for normal ruminant requirements. Significantly decreased $(p<0.05)$ level of sodium content was observed in soil, forages as well as blood samples. The existing mineral deficiency problems might be due to the animal are fed on forages that are deficient in sodium Content due to sandy soils in that particular site, where leaching of nutrients is a major problem. So, the consumption of materials with an appropriate dose of minerals mix is recommended for proper growth and reproduction of animals of commercial values.

Keywords: Blood; Forage, Goat; Pakistan; Plasma; Sheep; Sodium

\section{Introduction}

The quantities, as well as the quality of forages, improve the health, growth and productivity rate of livestock and have a better effect on livestock and human health. The source of mineral for grazing livestock is forage and other than forage is water and soil from which animal obtain minerals [1]. Mineral status of soil and hence forages defined the status of grazing livestock in that area, as well as many other animal factors, play an important role $[2,3]$. The deficiency 
or excess of particular minerals is due to a diet of ruminants which indicate the level of mineral concentration of serum consistently higher or below the normal concentration [4]. Impaired reproduction in livestock, infertility, tetany, and bone abnormalities are caused by mineral deficiency and mineral imbalance in soil and forage [5].

Nutritional requirement for reproduction and growth of plants are essential like animals [6, 7]. If insufficient minerals are present in the soil, then plants react either by reducing the concentration of minerals in their tissues or reducing the plant growth [8-10]. The level of minerals in the plant is affected by the level of mineral in soil and exerts its importance through the mineral impact on soil $\mathrm{pH}$, which can increase or limit the ability of plants to integrate minerals in their tissues [11].

Sodium is one of the most intensely researched ion in plant biology and has gained an attention for its toxic qualities. However, sodium is beneficial mineral for many plants at lower level but not required for plant growth [12]. Plants can be grouped on the basis of soil type and on the basis of their sodium uptake. Halophytes are grown in saline soil and can tolerate sodium content in the soil. Natrophiles are salt-loving plants and grow best in saline soil, whereas natrophobes are salt-hating plants with as low as $2 \mathrm{~g} / \mathrm{kg}$ sodium content. Classification of forages on the basis of sodium accumulation is not clear [13].

Sodium is very important extracellular cation in animals and performs many key functions in animal metabolisms such as nutrient absorption and transport, muscles movement, in the central nervous system, electrolyte and water balance [14]. It was observed that in Kentucky mostly animal breeders like beef cattle producers ensure complete mineral mix to their herds. Same diet pattern including minerals mix was observed by the grazing systems researchers at the Forage Systems Research Center of the University of
Missouri in Linneus. Complete mineral mixtures not only act as bloat preventing agents but also provide macronutrients and micronutrients and serve as larvacides, rumen modifiers (e.g., monensin, lasalocid etc.) Cattle have senses like humans to discriminate between different taste like salt, sweet, sour and bitter tastes due to the presence of taste buds. They are very selective and if given the opportunity, consume forage with more salt needed for their physiological processes [15]. This study was carried out (1) to examine the sodium level in soil, forages and blood samples of the small ruminants (goat and sheep), (2) to determine the bioconcentration factor of sodium and (3) to appraise the pollution severity of soil due to sodium.

\section{Materials and methods \\ Study site}

The presents study was conducted in different districts of Punjab such as Sargodha, Mianwali and Bhakkar (Figure 1). Three sites from each district were chosen for the collection of different samples of soil, forages and blood of animals (goat and sheep).

Sargodha, an important district of Punjab, is situated $172 \mathrm{~km}$ northwest from Lahore, Pakistan. Sargodha comprises of different industries and center of agricultural trade. Different interchanges connect it at various locations. Plain, fertile lands, small hills and cold and hot weather are characteristics of Sargodha. The temperature in winter recorded as low as freezing point and the summer the maximum up to $50^{\circ} \mathrm{C}\left(122^{\circ} \mathrm{F}\right)$. In the $16^{\text {th }}$ century a local saint, Mian Ali derives the name of the city as Mianwali located near the bank of Indus. Mianwali positioned between $71-08^{\circ}$ to $71-57^{\circ}$ East longitudes and $32-10^{\circ}$ to $33-15^{\circ}$ North latitudes. The annual maximum temperature recorded as $47^{\circ} \mathrm{C}$ and the minimum temperature recorded as $19{ }^{\circ} \mathrm{C}$. The maximum rainfall occurs in the month of July 
oly mostly the area is arid or semi-arid. Some important crops such as mung, mash, verin, barley, Eruca, fennel, wheat, oat, mustard, and pea nut etc. are cultivated in this area. Soil is sandy, clay and loamy in this district. In Pakistan, after slicing of Mianwali area a new district named as Bhakkar in 1982 was established. It is located at the left side of the bank of Indus River and at an altitude of 159 $\mathrm{m}$. Between Chenab and Indus river district Bhakkar is situated. It is located in deserted plains of Thal desert and consists of a riverine tract along the Indus, called Kaccha. It consisted of sandy land and of semirectangular shape. Bhakkar district occupies $8153 \mathrm{~km}$ total area.

\section{Samples collection}

Soil, forages and blood samples (10 each) were collected randomly from each site. Ten samples of each were combined and make three composite samples.

\section{Soil}

For a collection of soil samples, three different sites were selected in three districts (Sargodha, Mianwali and Bhakhar). Soil layers about $12-15 \mathrm{~cm}$ were dug up with the help of stainless-steel auger [16]. From each investigated site ten samples were obtained from three districts, stored in a plastic bag.

\section{Forage}

Forages were also collected from these sites which were selected for soil sampling by mean of sterilized apparatus. Only these forages species were collected which were commonly used for feed of the small ruminants (sheep and goat). Forage species which were selected as samples include Bajra (Pennisetum glaucum), Barsem (Trifolium alexandrinum) and Oat (Avena sativa). Ten samples of these forages were taken from three sites of three districts. Distilled water was used to eliminate impurities and $\mathrm{HCl}$. Samples were dried to remove moisture content were placed in sunlight.

\section{Blood plasma}

Blood samples of goat and sheep were collected from the Bhakkar, Mianwali, and Sargodha in 2016. Goat and sheep of one year old were selected for sampling. Each district divided into three sites. Five goats of each site were selected, and data were pooled into one mean value. From jugular vein sample of blood was collected through the needle of the syringe which was firstly sterilized. The vacuum was created into evacuated tubes or to avoid from clotting were retained in the heparinized Na-citrate voiles rapidly. At $3000 \mathrm{rpm}$ blood was centrifuged $15 \mathrm{~min}$ and blood plasma, stored in polyethylene tubes and frozen at $-20{ }^{\circ} \mathrm{C}$.

\section{Sample preparation \\ Soil and forage samples}

Soil and forage samples were air dried and then oven dried at $72^{\circ} \mathrm{C}$ until no moisture content remained then removed from oven and the weight of samples were done by using the electric balance. Samples were digested by standard procedure [17]. $1 \mathrm{~g}$ sample, 10 $\mathrm{mL}$ nitric acid was taken in a beaker and placed it overnight. Next day samples were digested on a hot plate, $\mathrm{H}_{2} \mathrm{O}_{2}$ was also added drop by drop until a colorless solution appeared. Then removed from the hot plate and placed it for cooling and then distil water was added up to $50 \mathrm{~mL}$ and filtered through Whatman filter paper of $42 \mu \mathrm{m}$ size, stored for further process.

\section{Blood plasma}

Blood samples of goats and sheep collected from three districts were frozen at $-20{ }^{\circ} \mathrm{C}$. Blood samples removed from freezer and samples of blood were digested by the same procedure [17].

\section{Digestion}

One $\mathrm{mL}$ of blood samples (goat and sheep) was taken for digestion and mixed in $10 \mathrm{~mL}$ $\mathrm{HNO}_{3}$ and placed it overnight. Samples were put on a hot plate and $\mathrm{H}_{2} \mathrm{O}_{2}$ added drop by drop and fumes get evaporated. The process remains continued until the colorless solution 
appeared. Samples were digested and removed from the digestion chamber and left the solution for cooling. Distilled water was added to make its volume up to $50 \mathrm{~mL}$ and then the solution was filtered through Whatman filter paper $42 \mu \mathrm{m}$ size and stored in plastic bottles till analysis.

\section{Sodium analysis}

Sodium content in soil, forage and blood samples of goat and sheep was determined by Flame photometer [18].

\section{Quality control}

Precision and accurateness of analyses were assured through repetitive samples against National Institute of Standard Technology, Standard reference material (SRM 2709 for soil, SRM 1570 for forages and SRM 955c for animal blood) for sodium. The results were found within $\pm 2 \%$ of the certified value.

\section{Statistical analysis}

SPSS 22 software was used for ANOVA and to find out the mean values of metals and the relationship between metals of soil and forages correlation coefficient was used at significance level 0.05 [19].

\section{Pollution load index}

The pollution load index (PLI) was used to measure the contamination of metals in investigated soil following the method of Liu et al. [20].

$\mathrm{PLI}=$ Metal contamination in soil/Reference metal value in soil

\section{Bioconcentration factor}

Bioconcentration factor (BCF) was used to assess the content of metals in soil-forages and forage-ruminants blood in $(\mathrm{mg} / \mathrm{kg})$ following Cui et al. [21].

$\mathrm{BCF}=$ Metals contents in forages/ Metals contents in soil

$\mathrm{BCF}=$ Metals contents in blood / Metals contents in forage.

\section{Results}

\section{Soil}

The results from ANOVA showed a nonsignificant effect $(p<0.05)$ of sodium in soil collected from different sites of three districts
(Table 1). In district Sargodha, the mean sodium concentrations in the soil which were used for cultivation of forages were between $73.54-80.97 \mathrm{mg} / \mathrm{kg}$. In Mianwali, the mean sodium concentrations in soil were between $76.5-78.74 \mathrm{mg} / \mathrm{kg}$. In Bhakkar, the mean sodium concentrations were between 53.62$63.58 \mathrm{mg} / \mathrm{kg}$ (Figure 2).

\section{Forages}

The results from ANOVA showed a nonsignificant effect $(p<0.05)$ of sodium in forages collected from different sites of three districts (Table 1). In district Sargodha, the mean sodium contents in forages used for feeding purpose were between 59.6-76.34 $\mathrm{mg} / \mathrm{kg}$. In Mianwali, the mean sodium contents in forages were between 67.44$69.22 \mathrm{mg} / \mathrm{kg}$. In Bhakkar, the mean sodium contents were between $58.84-70.41 \mathrm{mg} / \mathrm{kg}$ (Figure 3).

\section{Blood of goat}

The results depicted a non-significant effect $(p<0.05)$ of sodium in blood samples of goats collected from different sites of three districts (Table 1). In district Sargodha, the mean sodium contents in blood samples of goats which consumed the contaminated forages were between 51.36-60.44 $\mathrm{mmol} / \mathrm{L}$. In Mianwali, the mean sodium contents in the blood plasma of goats were between 56.78$61.06 \mathrm{mmol} / \mathrm{kg}$. In Bhakkar, the mean sodium contents were between 75.46-87.76 $\mathrm{mmol} / \mathrm{L}$ (Figure 4).

\section{Blood of sheep}

The results revealed a non-significant effect $(p<0.05)$ of sodium in blood samples of sheep collected from different sites of three districts (Table 1). In district Sargodha, the mean sodium contents in the blood plasma of sheep which consumed the contaminated forages were between 58.16-61.72 $\mathrm{mmol} / \mathrm{L}$. In Mianwali, the mean sodium contents in the blood plasma of sheep were between 51.4$61.69 \mathrm{mmol} / \mathrm{L}$. In Bhakkar, the mean sodium contents were between 41.33-49.99 $\mathrm{mmol} / \mathrm{L}$ (Figure 5). 


\section{Correlation}

The relationship between mineral contents was established [22]. A perfect negative correlation was observed in the soil to forage, soil to blood and positive correlation of sodium was studied in forages to the blood of the goat and forage to the blood of sheep samples in Sargodha.

A perfect positive correlation was observed in the soil to forage, soil to blood and forages tothe blood of the goat and high negative were observed the sodium interrelation among soil and blood of sheep and between forage and serum of sheep in Mianwali samples. A perfect positive correlation was observed in the soil to the blood of sheep and forages to the blood of the goat and high negative were observed the sodium interrelation among soil to forage, soil to the blood of the goat and between forage to the serum of sheep in Bhakhar samples (Table 2)

\section{Bioconcentration factor}

Bioconcentration factor of sodium for forage was higher in Bhakkar and Sargodha than Mianwali. The least $\mathrm{BCF}$ value of $\mathrm{Na}$ was observed in Mianwali while maximum BCF value of sodium was seen in Bhakkar. The BCF of sodium for blood plasma of goats was higher in Bhakkar sampling as compare to Mianwali and Sargodha. Similarly, the BCF of sodium for blood plasma of sheep of Sargodha sampling was higher as compare to Bhakkar (Table 3).

\section{Pollution load index}

Pollution load indexfor sodium revealed higher in Sargodha and Mianwali soil as compare to Bhakkar (Table 4).

\section{Discussion}

Sodium is a non-essential element for the plant but can be used in small quantities, similar to micronutrients, to help in the metabolism and synthesis of chlorophyll. Mean values of sodium content in all soil samples were more than the critical level of $62 \mathrm{mg} / \mathrm{kg}$ as stated by Rhue and Kidder [23]. Espinoza et al. [24] also give the values in a similar range. Long term mineral deficiencies for animals in worldwide developing countries are highly affected by sodium such as Nigeria [25]. In contrast to these results, Khan et al. [11] also observed a high amount of sodium content in soil of another range in Punjab, Pakistan. Mineral status of plants defined the mineral status of animals of that area depending on soil types of the area [26]. It is suggested that sodium containing fertilizer should be used to increase the sodium content of the soil which is deficient in sodium content. The sodium content in soil varied in different pastures. The soils in Mianwali and Bhakar districts are deep sandy soils and nutrients quickly leached beyond the root zone of forage plants.

Sodium contents in soils did not differ significantly $(p<0.05)$ between different sites of three districts. Similar results were observed by Khan et al. [11, 27] while working in other pastures of the same district. Most of the forages analyzed contained minerals below the critical levels $(0.08 \%)$ for ruminant requirements $[28,29]$. The pastures contained the lowest forage $\mathrm{Na}$ levels, while variations among different pastures were found $(p>0.05)$ to be non-significant as reported by Khan et al. [30].

To cope with the $\mathrm{Na}$ deficiency among grazing ruminant supplementation is needed. Some earlier findings [31] also show that sodium deficiency is one of the most prevalent mineral deficiencies for grazing animals in developing countries like Nigeria [25], Colombia [32] and Pakistan [11, 30]. To meet the demand of ruminant, forage should be added more than $0.15 \% \mathrm{Na}$ content on dry matter basis [33].

Sodium contents in forages were below the recommended levels for good animal growth and production. For this purpose, $\mathrm{Na}$ intake of $0.87 \mathrm{~g} / \mathrm{kg}$ was recommended to maintain an adequate sodium and $\mathrm{K}$ ratio in the parotid saliva of goat and sheep [34]. 


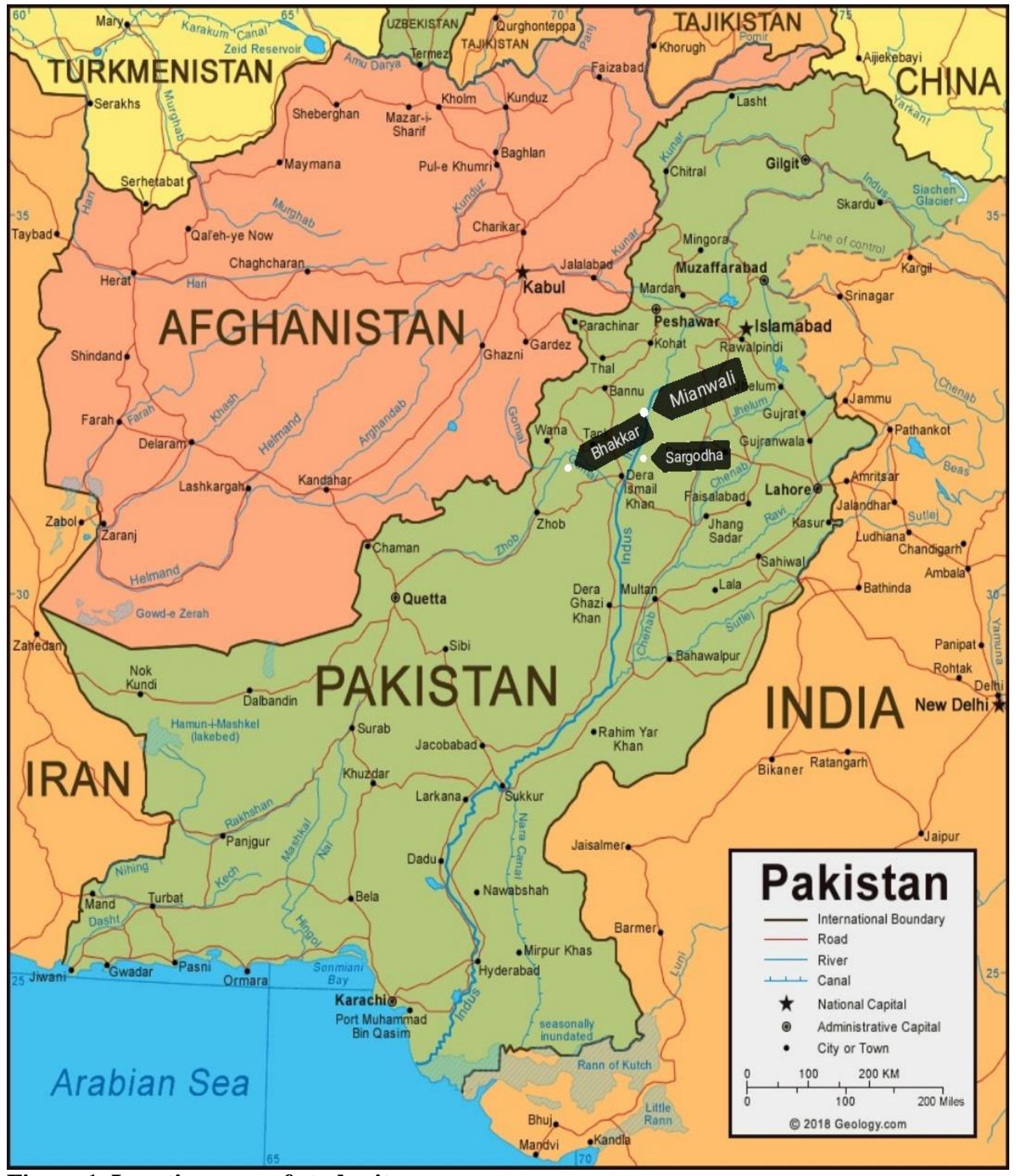

Figure 1. Location map of study site 


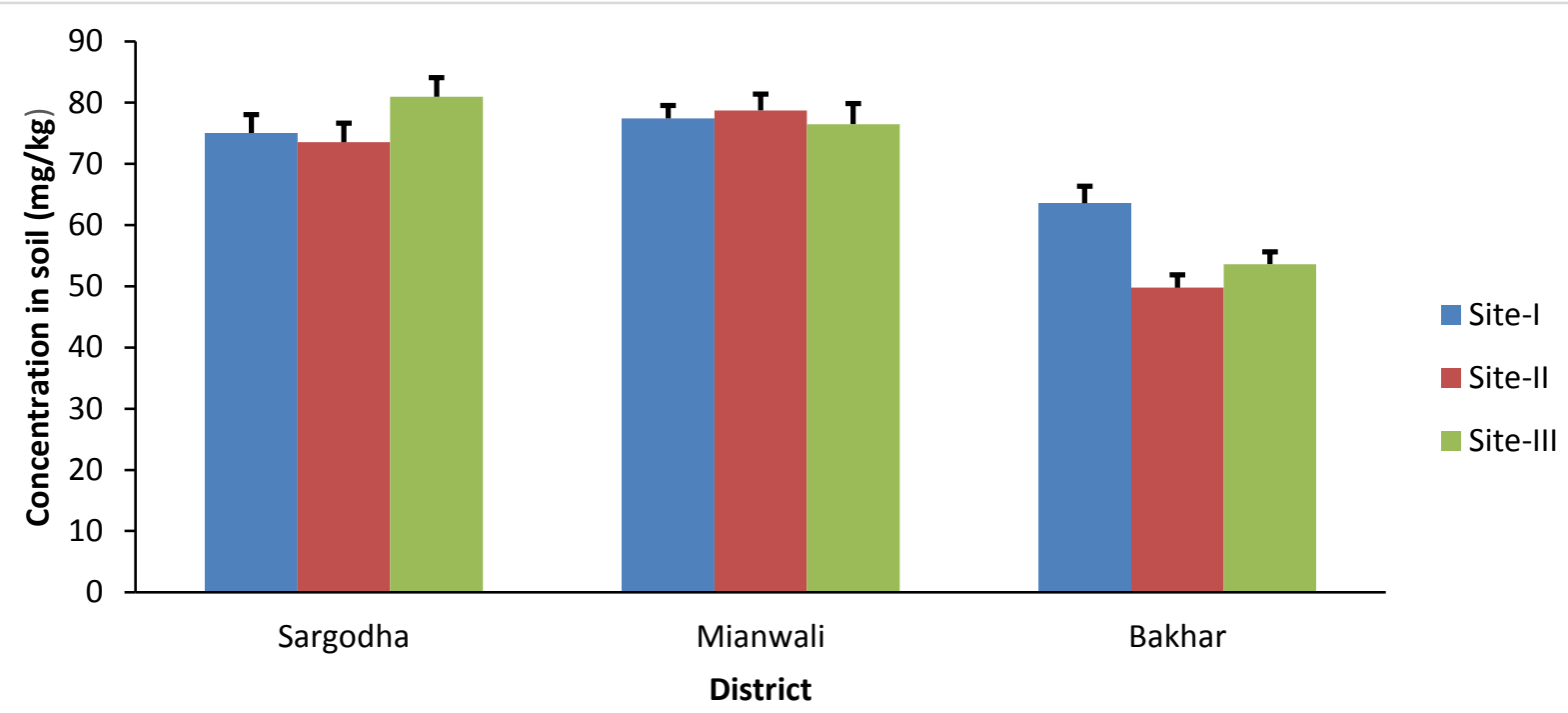

Figure 2. Mean sodium concentration in soil $(\mathrm{mg} / \mathrm{kg})$ in different districts of Punjab

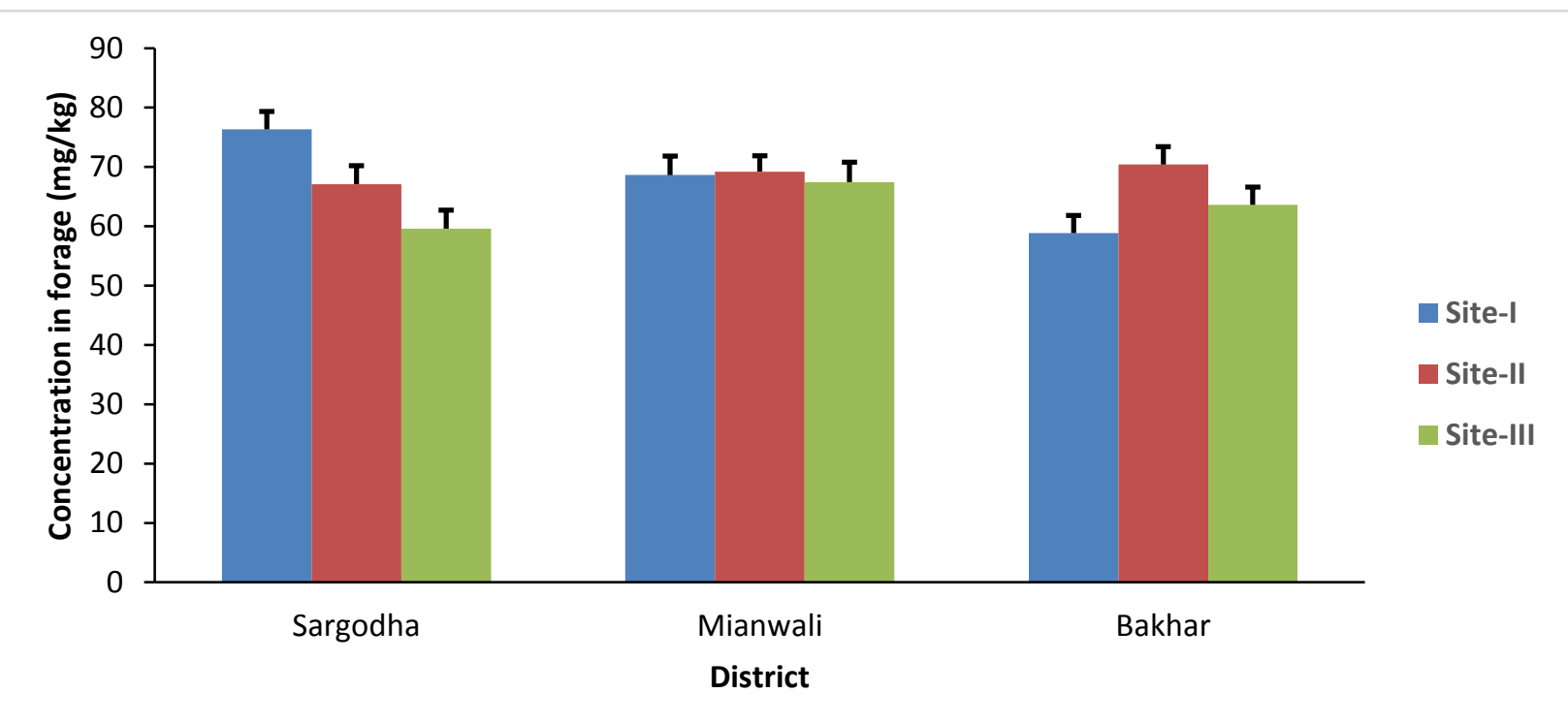

Figure 3. Mean sodium concentration in forages $(\mathrm{mg} / \mathrm{kg})$ in different districts of Punjab 


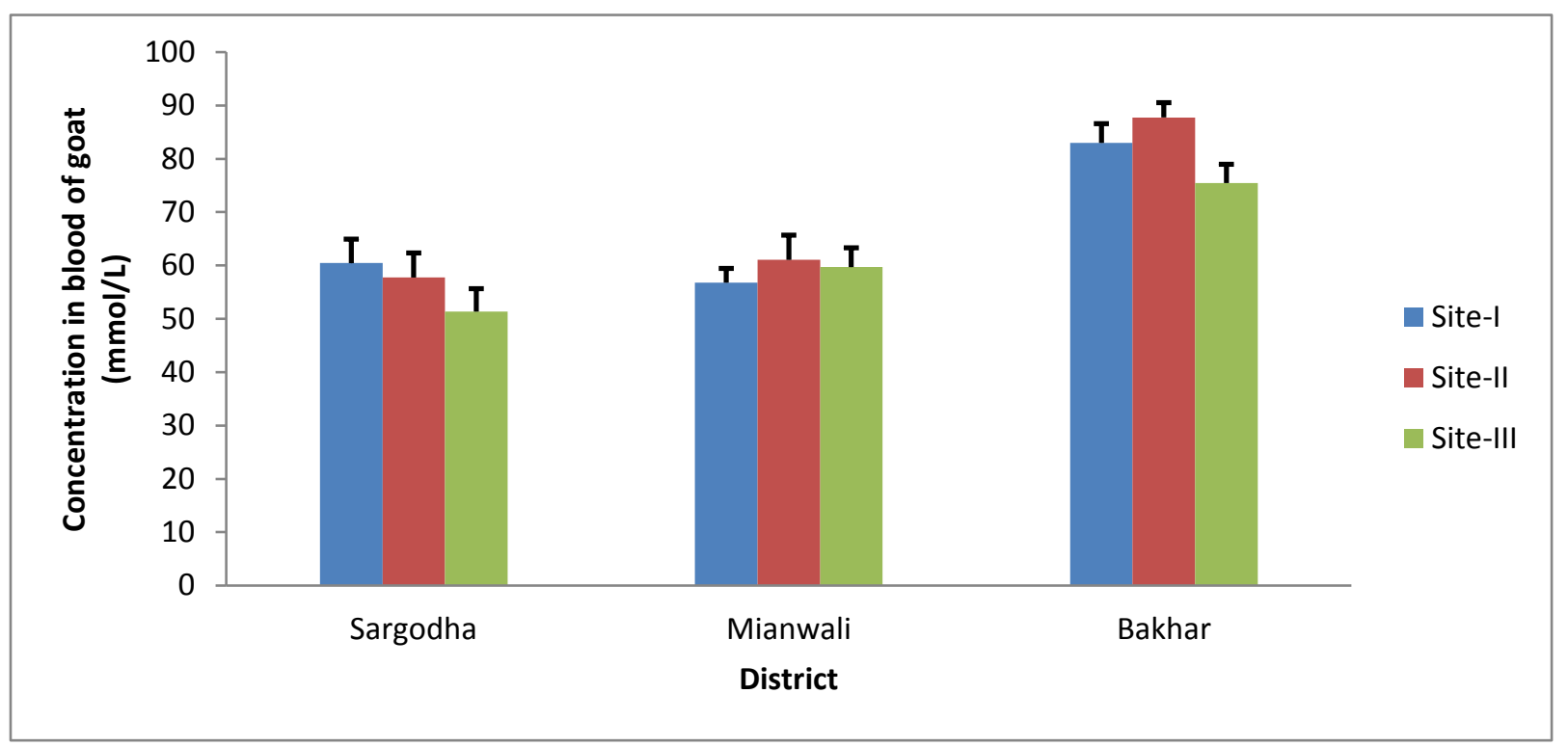

Figure 4. Mean sodium concentration in blood of goat $(\mathrm{mmol} / \mathrm{L})$ in different districts of Punjab

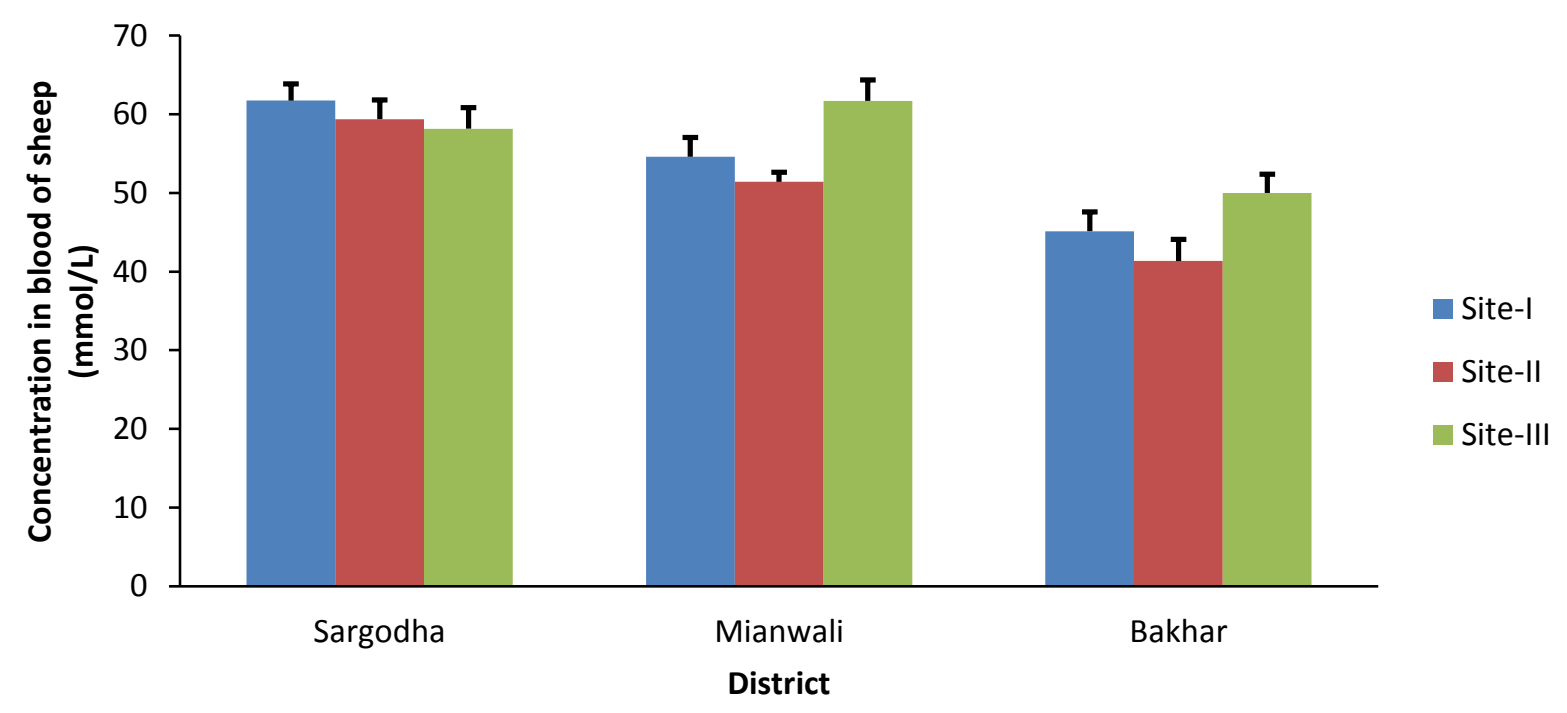

Figure 5. Mean sodium concentration in blood of sheep $(\mathrm{mmol} / \mathrm{L})$ in different districts of Punjab 
Table 1. Analysis of variance for sodium contents in soil, forage and blood plasma in three districts of Punjab

\begin{tabular}{|c|c|c|c|}
\hline Sodium & Sargodha & Mianwali & Bhakhar $^{\mathrm{na}}$ \\
\hline Soil & $46.347^{\mathrm{ns}}$ & $4.412^{\mathrm{ns}}$ & $81.228^{\mathrm{ns}}$ \\
\hline Forage & $210.394^{\mathrm{ns}}$ & $2.466^{\mathrm{ns}}$ & $101.511^{\mathrm{ns}}$ \\
\hline Blood of goat & $65.242^{\mathrm{ns}}$ & $14.327^{\mathrm{ns}}$ & $115.268^{\mathrm{ns}}$ \\
\hline Blood of sheep & $9.828^{\mathrm{ns}}$ & $48.400^{\mathrm{ns}}$ & $56.826^{\mathrm{ns}}$ \\
\hline Degree of freedom & 2 & Error & 8 \\
\hline
\end{tabular}

Table 2. Correlation of sodium between soil-forage and soil-blood of goat and sheep

\begin{tabular}{|c|c|c|c|c|c|}
\hline Soil & $\begin{array}{c}\text { Soil- } \\
\text { Forages }\end{array}$ & $\begin{array}{c}\text { Soil-Blood } \\
\text { of goat }\end{array}$ & $\begin{array}{c}\text { Soil-Blood of } \\
\text { sheep }\end{array}$ & $\begin{array}{c}\text { Forage-Blood of } \\
\text { goat }\end{array}$ & $\begin{array}{c}\text { Forage-Blood of } \\
\text { sheep }\end{array}$ \\
\hline Sargodha & -.714 & -.885 & -.623 & .958 & .992 \\
\hline Mianwali & .960 & .402 & -.951 & .130 & $-1.000^{*}$ \\
\hline Bhakkar & -.814 & -.899 & .922 & .476 & -.526 \\
\hline
\end{tabular}

Table 3. Bioconcentration of sodium in different districts of Punjab

\begin{tabular}{|c|c|c|c|c|}
\hline BCF of sodium & Sites & Sargodha & Mianwali & Bhakkar \\
\hline \multirow{3}{*}{ Soil-Forages } & 1 & 1.017 & 0.886 & 0.925 \\
\cline { 2 - 5 } & 2 & 0.912 & 0.879 & 1.414 \\
\cline { 2 - 5 } & 3 & 0.736 & 0.882 & 1.186 \\
\hline \multirow{3}{*}{ Forages-Blood of goat } & 1 & 0.792 & 0.827 & 1.410 \\
\cline { 2 - 5 } & 2 & 0.860 & 0.882 & 1.246 \\
\cline { 2 - 5 } & 3 & 0.867 & 0.885 & 1.186 \\
\hline \multirow{3}{*}{ Forages-Blood of sheep } & 1 & 0.808 & 0.795 & 0.767 \\
\cline { 2 - 5 } & 2 & 0.885 & 0.742 & 0.588 \\
\cline { 2 - 5 } & 3 & 0.976 & 0.915 & 0.786 \\
\hline
\end{tabular}

Table 4. Pollution load index sodium in different district of Punjab

\begin{tabular}{|c|c|c|c|}
\hline Site & Sargodha & Mianwali & Bhakkar \\
\hline 1 & 1.210 & 1.248 & 1.025 \\
\hline 2 & 1.186 & 1.27 & 0.802 \\
\hline 3 & 1.306 & 1.234 & 0.864 \\
\hline
\end{tabular}

Animal grazing on tropical pasture are more prone to sodium deficiencies because plant species in this area accumulate less sodium than temperate species [34]. Sodium deficiencies have been reported in numerous tropical countries throughout the world [35]. The non-significant correlation for sodium between soil and forage, soil to blood and forages to the blood of the goat, forages and blood of sheep which might be due edaphic factor might have led to a reduction in uptake of $\mathrm{Na}$. Sodium also revealed a non-significant positive correlation between soil tothe blood of sheep and forages to the blood of the goat and non-significant negative correlation was observed between soil to forage and soil to the blood of the goat, and non-significant positive correlation between forage and blood of goat which leads to sodium imbalance among soil plant and animals.

Bioconcentration factor of $\mathrm{Na}$ in forage was higher in Bhakkar and Sargodha samples as compared to Mianwali samples. Higher BCF values of $\mathrm{Na}$ in Bhakkar and Sargodha samples was observed while the lowest BCF value of $\mathrm{Na}$ was observed in Mianwali. Low 
BCF for Na in Mianwali might be due to the low $\mathrm{Na}$ uptake by forage species and periods have also affected the metal transmission and low Na level in animals present in Mianwali. The rate of metal uptake by the plant has been affected by the nature of the soil, soil $\mathrm{pH}$, plant species, plant age, and climate.

Pollution severity in the soil can be measured by PLI. According to this method, soil is considered to be polluted if PLI value was higher than 1, while the soil is considered to be clean or less dirty if PLI value is less than 1 [36]. The pollution level or contamination factor of sodium was greater than 1 and soil considered to be polluted.

\section{Conclusion}

The study indicated the existence of potential mineral deficiency problems since animal is fed on forages that are deficient in sodium content due to sandy soils in that particular sites, where leaching of nutrients is a major problem. The soils in these areas are also deficient in sodium content. So, the consumption of materials with an appropriate dose of minerals mix is recommended for proper growth and reproduction of animals of commercial values. There is an urgent need for appropriate experimentation so that soundly based supplementation packages can be devised.

\section{Authors' contributions}

Conceived and designed the experiments: ZI Khan, K Ahmad \& IR Noorka, Performed the experiments: S Siddique \& K Wajid, Analyzed the data: M Akhtar H Muqadas \& P Akhtar, Contributed reagents/ materials/ analysis tools: $\mathrm{H}$ Bahir, $\mathrm{N}$ Mehmood, $\mathrm{M}$ Nadeem \& I Ugulu, Wrote the paper: IS Malik, M Shehzadi, A Ashfaq \& M Munir.

\section{References}

1. Ahmad K, Nawaz K, Khan ZI, Nadeem M \& Wajid K et al. (2018). Effect of diverse regimes of irrigation on metals accumulation in wheat crop: An assessment-dire need of the day. Fresen Environ Bull 27(2): 846-855.
2. Khan ZI, Ugulu I, Sahira S, Ahmad K, Ashfaq A, Mehmood N \& Dogan Y (2018). Determination of Toxic Metals in Fruits of Abelmoschus esculentus Grown in Contaminated Soils with Different Irrigation Sources by Spectroscopic Method. Inter J Environ Res 12: 503-511.

3. Khan ZI, Ugulu I, Umar S, Ahmad K, Mehmood N, Ashfaq A, Bashir H \& Sohail M (2018). Potential toxic metal accumulation in soil, forage and blood plasma of buffaloes sampled from Jhang, Pakistan. Bullet Environ Contamin Toxicol 101: 235-242.

4. Underwood E J \& Suttle NF (1999). The mineral nutrition of livestock. (3rd Ed.). Midlothian, UK, pp 283-392.

5. Kadzere CT, Murphy MR, Silanikove N, Maltz E (2002). Heat stress in lactating dairy cows: a review. Livest Sci 77(1): 59-91.

6. McDowell LR \& Valle G (2000). Major minerals in forages. In: Forage Evaluation in Ruminant Nutrition (D. I. Givens, E.Owen, R. F. E. Oxford and H. M. Omed). CAB International, Wallingford, UK, pp 373.

7. Khan ZI, Ugulu I, Ahmad K, Yasmeen S, Noorka IR, Mehmood N \& Sher M (2018). Assessment of trace metal and metalloid accumulation and human health risk from vegetables consumption through spinach and coriander specimens irrigated with wastewater. Bull Environ Contam Toxicol 101(6): 787-795.

8. Ugulu I (2015). Determination of heavy metal accumulation in plant samples by spectrometric techniques in Turkey. Appl Spectrosc Rev 50(2): 113-151.

9. Ugulu I (2015). A quantitative investigation on recycling attitudes of gifted/talented students. Biotech Biotechnol Equip 29: 20-26. 
10. Nadeem M, Qureshi TM, Ugulu I, Riaz MN, An QU, Khan ZI, Ahmad K, Ashfaq A, Bashir H \& Dogan Y (2019). Mineral, vitamin and phenolic contents and sugar profiles of some prominent date palm (Phoenix dactylifera) varieties of Pakistan. Pak J Bot 51(1): 171-178.

11. Ugulu I, Unver MC \& Dogan, Y (2016). Determination and comparison of heavy metal accumulation level of Ficus carica bark and leaf samples in Artvin, Turkey. Oxidation Communic 39(1): 765-775.

12. Kronzucker, HJ Coskun D \& Schulze LM et al. (2013) Sodium as nutrient and toxicant. Plant Soil 369(1): 1-23.

13. Martz FA, Gerrish JR, Morrol RE \& Peterson PR (1993) Macromineral intake of Polled Hereford cows in four grazing systems. 1993 AFGC Proceedings, pp 95-99.

14. Smith OB, Kasali OB, Adeyanju SA \& Adegbola AA (1980). Mineral nutrition in tropical livestock, Potassium deficiency in bovine. J Animal Sci 51: 396.

15. Minson DJ (1990) Forage in Ruminant Nutrition. Academic Press.

16. Sanchez IC \& Lacombe RH (1976). An elementary molecular theory of classical fluids. Pure fluids. J Phys Chem 80(21): 2352-2362.

17. Vukadinovic V \& Bertic B (1988). Agrochemistry and plant nutrition. University JJ. Strossmayer in Osijek, Faculty of Agriculture (in Croatian), Osijek. 56.

18. Khan ZI, Ahmad K, Raza N, Al-Qurainy F, Ashraf M \& Hussain A (2010). Assessment of chromium concentrations in soil-plant-animal continuum: Possible risk for grazing cattle. Pak J Bot 42(5): 3409-3414.

19. Steel RGD \& Torrie JH (1980). Principles and procedures of statistics, A Biometrical approach, (2nd Ed.). McGraw Hill, New York.
20. Liu W, Zhao JZ, Ouyang ZY, Soderlund L \& Liu GH (2005) Impacts of sewage irrigation on heavy metal distribution and contamination in Beijing, China. Environ Inter 31: 805-812.

21. Cui YL, Zhu RH, Zhi RH, Chen DY, Huang YZ \& Qiu Y (2004). Transfer of metals from soils to vegetables in an area near a smelter in Nanning, China. Environ Int 30: 785-791.

22. Pentecost A (1999). The origin and development of the travertines and associated thermal waters at Matlock Bath, Derbyshire. P Geologist Assoc 110(3): 217-232.

23. Rhue RD \& Kidder G (1983). Analytical procedures used by the IFAS extension soil testing laboratory and the interpretation of results. Soil Science Department University of Florida, Gaine.

24. Espinoza JE, McDowell LR, Wilkinson NS, Conrad JH \& Martin FG (1991). Monthly variation of forage and soil minerals in Central Florida. II. Trace Minerals. Commun Soil Sci Plant Anal 22: 1137-1149.

25. Ogebe PO, Ayoade JA, McDowell LR, Wilkinson NS \& Martin FG (1995). Mineral concentrations of forages and soils in Benue State, Nigeria. I. Macrominerals and forage in vitro organic matter digestibility and crude protein concentrations. Commun Soil Sci Plant Anal 26(13-14): 1989-2007.

26. Mtimuni JP (1982). Identification of mineral deficiencies in soil, plant and animal tissues as constraints to cattle production in Malawi. Ph.D. Dissertation University of Florida, Gaines.

27. Khan ZI, Hussain A, Ashraf M \& McDowell LR (2006). Mineral Status of Soils and forages in southwestern Punjab-Pakistan: Micro-minerals. Asian-Australian J Animal Sci 19(8): 
1139-1147.

28. McDowell LR, Ellis GL \& Conrad JH (1984). Mineral Supplementation for Grazing Cattle in Tropical Regions. World Animal Review.

29. Anonymous (1984). Analytical Methods for Atomic-Absorption Spectrophotometry. Perkin-Elmer, Norwalk, Connecticut.

30. Khan ZI, Hussain A, Ashraf $M$ \& Ermidou-Pollet S (2007). Transfer of iron from soil and forage to sheep grazing in a semiarid region of Pakistan. Influence of the seasons and the period of sampling. Trace Elem Electron 42: 166-172.

31. McDowell LR, Conrad JH \& Hembry FG (1993). Minerals for Grazing Ruminants in Tropical Regions. University of Florida, Gainseville.
32. Pastrana R, McDowell LR, Conrad JH \& Wilkinson NS (1991). Macro mineral status of sheep in the Paramo region of Colombia. Small Ruminant Res 5: 9-21.

33. Anonymous (2006). Economic Survey. Government of Pakistan, Finance Division, Islamabad, Pakistan,

34. Morris JG (1980) Assessment of sodium requirements of grazing beef cattle. $J$ Animal Sci 50: 145-152.

35. McDowell LR (1985). Nutrition of Grazing Ruminants in Warm Climates. Academic Press New York, pp 443.

36. Harikumar PS, Nasir UP, Mujeebu MP \& Rahma (2009). Distribution of heavy metals in the core sediments of a tropical wetland system. Inter J Environ Sci Tech 6(2): 225-232. 